\title{
Turizm İşletmelerinin İhtiyaç Duyduğu Danışmanlık Hizmetleri: Kastamonu Örneği
}

\author{
Ali ŞENGÜL* \\ Hüseyin PAMUKÇU ${ }^{+}$ \\ Semih ARICI ${ }^{\ddagger}$
}

\begin{abstract}
$\ddot{\mathbf{O z}}$
Bir işletmenin büyümesi ya da bir işletmede zorunlu olarak küçülmeye gidilmemesi için sürekli değişmekte olan şartlara ayak uydurulması gerekmekte ve bu sürecin olumlu bir şekilde ilerleyebilmesi için de profesyonel destek alınmalıdır. Destinasyonlarda turistlere, konaklama, yeme-içme, ulaşım vb. hizmetler sunan ve turizm sektörünün önemli halkalarından biri olan turizm işletmelerinin de bu şartlara uyum sağlaması gerekmektedir. Bu çalışmada, turizm işletme sahiplerinin/yöneticilerinin turizm sektörüne yatırım kararı verdikten önceki ve sonraki süreçlerde hangi danışmanlık hizmetlerine ihtiyaç duyduklarının belirlenmesi ve bu konudaki eksik yönlerin saptanması hedeflenmiştir. Nitel olarak yapılan bu çalışmada; Kastamonu ilindeki turizm işletmelerinin bu sektöre yatırım yapma kararı öncesinde, yatırım sürecinde ve yatırım yaptıktan sonraki süreçlerde ne gibi araştırmalar yaptıkları, bu süreçte karşılaştıkları sorunları nasıl aştıkları ve herhangi bir danışmana ihtiyaç duyup duymadıkları gibi konular mülakat tekniği kullanılarak tespit edilmeye çalışılmıştır. Elde edilen veriler betimsel analiz tekniği kullanılarak çözümlenmiştir. Yapılan analizler sonucunda, işletmelerin danışmanlık hizmetine ihtiyaç duymadıkları ve herhangi bir kurum ya da kuruluştan yardım almadıkları belirlenmiştir. Ayrıca elde edilen sonuçlara göre, bu işletmelerin karşılaşıtıları ya da karşılaşabilecekleri sorunları yakın çevresiyle birlikte çözmeye çalıştıkları belirlenmiştir.
\end{abstract}

Anahtar Kelimeler: Turizm, Turizm İşletmeleri, Danışmanlık Hizmeti, Kastamonu.

\section{Consultancy Services Needed by Tourism Enterprises: The Case of Kastamonu}

Abstract

In order for a business to grow or not to be forced to downsize in a business, it is necessary to keep up with the ever-changing conditions and professional support should be obtained in order for this process to proceed in a positive way. Tourism enterprises, which provide services such as accommodation, food and drink, transportation and etc. to tourists in destinations and are one of the important rings of the tourism sector, must also adapt themselves to these conditions. In this study, it is aimed to determine what consultancy services tourism business owners/managers need in the processes before and after making an investment decision in the tourism sector and to determine the deficiencies in this issue. In this qualitative study; prior to the decision of tourism enterprises in Kastamonu province to invest in this sector, topics such as what research they conducted in the investment process and in the processes after investing, how they overcome the problems they faced in this process and whether they needed any consultants were tried to be identified using the interview technique. The data obtained were analyzed using the descriptive analysis technique. As a result of the analysis, it was determined that the enterprises did not need consultancy services and did not receive assistance from any institution or organization. In addition, according to the results obtained, it has been determined that these enterprises are trying to solve the problems they face or may encounter together with their close circle.

Keywords: Tourism, Tourism Enterprises, Consultancy Service, Kastamonu.

Geliş/Received: 24.02 .2021

Kabul/Accepted: 22.06 .2021

* Bu çalışma için, Kastamonu Üniversitesi Sosyal ve Beşerî Bilimler Araştırma ve Yayın Etiği Kurulu'ndan 25.12.2020 tarih ve 90 sayılı karar ile etik kurul izni alınmıştır.

\footnotetext{
* Tezli Yüksek Lisans Öğrencisi, Kastamonu Üniversitesi Sosyal Bilimler Enstitüsü Turizm İşletmeciliği Anabilim Dalı İnanç Turizmi Bilim Dalı, alisengu1666@gmail.com, ORCID: 0000-0002-3909-6893

+ Doç. Dr., Afyon Kocatepe Üniversitesi Turizm Fakültesi Turizm İşletmeciliği Bölümü, pamukcuhuseyin@gmail.com, ORCID: 0000-0002-9673-5604

${ }^{\ddagger}$ Dr. Öğr. Üyesi, Pamukkale Üniversitesi Turizm Fakültesi Turizm Rehberliği Bölümü, sarici@ pau.edu.tr, ORCID: 0000-0003-0674-4337

(Araştırma Türü: Araştırma Makalesi)
} 


\section{Giriș}

Turizm sosyal ve ekonomik farklılıklardan oldukça etkilenen bir sektördür. Gündelik hayatında çeşitli problemlerle karşılaşan ve bunlardan dolayı gerginleşen bireyler, tüm bu problemlerden ve gerginlikten uzaklaşarak, sosyal ihtiyaçlarının en güzel şekilde giderilmesini temenni etmektedirler. Bundan dolayı turistlerin, tatil amaçlı yaptıkları seyahatlerde konaklama, yeme-içme ve eğlence gibi ihtiyaçları ortaya çıkmaktadır. Ekonomik açıdan destinasyonlar arasında önemli bir gelir sağlayan bu olay, turizm olarak adlandırılmaktadır (Akmel, 1992).

Geçici bir süreyle sürekli yaşanılan bölgeden başka bir bölgeye seyahat etme olayından doğan seyahat ve konaklama ihtiyaçlarının ve buna bağlı olarak diğer ihtiyaçların giderilmesini sağlayan mal ve hizmetlerin üretilmesinde ve pazarlamasında maddi kazanç sağlanması amacı güden birimlere turizm işletmeleri denmektedir (Akbaba, 2012). Sosyal ve ekonomik farkl11ıklardan en fazla etkilenen sektörlerden birisi olan turizm sektöründe, turizm işletmelerinin de bu sosyal ve ekonomik farklılıkları dikkate alarak işletmelerini bu durumlara göre yönetmeleri gerekmektedir.

Bir işletmeyi yönetmek, kontrol altına alınabilen ve kontrol altına alınamayan birçok faktörü uyumlu bir biçimde idare edebilme durumudur. İşletmeler, bu faktörlerden kontrolü dışında gerçekleşen çoğu faktörü değiştirme hakkına sahip olmadığından dolayı bu faktörlere uyum sağlamak zorundadır. Kontrol altına alabildiği faktörleri ise en faydalı şekilde kullanmak zorundadır. Bu faktörlere en iyi örneğin danışmanlık hizmeti olduğu ele alındığında, bu hizmet verimli bir düzeyde kullanıldığında üretim, pazarlama, finans, Ar-Ge gibi işletmenin gelişmesinde ya da gerilememesinde en önemli faktörlerden olan bu temel fonksiyonları en verimli şekilde yerine getireceği düşünülmektedir (Kayabaşı, 2009).

Geçici bir süre ile bilgi, beceri ve tecrübesinden yararlanarak, işletmenin büyümesi ya da küçülmemesi için, işletmelerin problemlerini belirleyen, var olan problemler üzerine çalışan, bu sorunlara çözüm önerileri getiren ve işletme yöneticilerine bu önerileri ileten kişiye "danışman" denmektedir (Aytar, 1999:16, Nural, 1991:45).

$\mathrm{Bu}$ çalışmanın amacı, turizm işletme sahiplerinin/yöneticilerinin turizm sektörüne yatırım kararının öncesi ve sonrasındaki süreçlerde hangi danışmanlık hizmetlerine ihtiyaç duyduklarının belirlenmesi ve bu konudaki eksik yönlerin saptanmasıdır. Bu çalışma, turizm işletmelerinde danışmanlık algısının oluşması/gelişmesi, turizm işletmelerine danışmanlık hizmeti sunan firmaların bu işletmelere daha fazla önem vermeleri ve bundan sonraki çalışmalara fayda sağlaması yönünden önem arz etmektedir. Bu çalışma kapsamında Kastamonu ili kent merkezinde yer alan konaklama ve yiyecek-içecek işletmelerinin sahipleri ve üst düzey yöneticileriyle görüşülmüştür. Turizm sektörüne yatırım yapmaya karar verirken hangi konularda danışmanlık hizmetine ihtiyaç duyulduğu, yatırım kararı verildikten sonra ne gibi araştırmalar 
yapıldığı ve hangi konularda danışmanlık hizmetine ihtiyaç duyulduğu ve yatırım sürecinde karşılaşılan engel ya da zorlukların nasıl aşıldığı gibi sorulara yanıtlar aranmıştır.

\section{Turizm İşletmeleri}

Barutçugil (1989:15) turizmi, maddi gelir sağlama amacı gütmemek ve gidilen yere daimi olarak yerleşmemek şartıyla turistlerin bir yerlere seyahatleri ve orada konaklamalarının sonucunda ortaya çıkan olayların ve ilişkilerin tümü olarak açıklamaktadır ve ona göre turizmin belirleyici özellikleri şunlardır: turizm, sürekli ikamet edilen, çalışılan ve doğal ihtiyaçların karşılandığı yerler dışında yapılan seyahatlerdir, turizm sektöründe konaklama geçici bir süreyi kapsar, seyahat eden ve konaklayan kişi bir süre sonra sürekli yaşadığı yere geri döner, seyahat eden ve geçici olarak konaklayan turistler çoğunlukla turizm işletmeleri tarafindan üretilen ve sunulan mal ve hizmetleri talep eder ve tüketirler. Burada bahsedilen turizm işletmeleri, sürekli yaşadığ1 yerden başka bir yere giden bireylere, kısacası turistlere, temel hizmetler sunan işletmelerdir.

Bireylerin geçici bir süreyle sürekli yaşanılan bölgeden başka bir bölgeye seyahat etme olayından doğan seyahat ve konaklama ihtiyaçlarının ve buna bağlı olarak diğer ihtiyaçların giderilmesini sağlayan mal ve hizmetlerin üretilmesinde ve pazarlamasında maddi kazanç sağlanması amacı güden birimlere turizm işletmeleri denmektedir (Akbaba, 2012). Turizm sektörünün sürekli bir biçimde büyümesi ve buna bağlı olarak da karmaşılaşması, farklı nitelikler barındıran turizm işletmelerinin gelişmesine ve kurulmasına neden olmaktadır. Tüm bu işletmelerin incelenebilmesi için de kategorize edilmeleri gerekmektedir (Şenel, 2007).

Bu kategoriler farklı şekillerde sınıflandırılabilir. Bu sınıflandırma; ulaştırma işletmeleri, konaklama işletmeleri, yiyecek-içecek işletmeleri, tur operatörleri/seyahat acenteleri, spor, eğlence ve dinlenme tesisleri, toplantı, seminer ve kongre merkezleri, yat işletmeciliği vb. şeklinde yapılırken, aynı zamanda bu işletmeler yerine getirdikleri fonksiyonlar açısından, yapılan faaliyetin türüne göre, kuruluş amacına göre, faaliyet alanına göre, işletmenin mülkiyetine göre ve kuruluşları ve çalışmaları bakımından turizme bağımlılıklarına göre de siniflandırılmaktadır. Bu siniflandırmalar sirasıyla, turizm mal ve hizmeti üreten ve bunları pazarlayan turizm işletmeleri, kâr amacı güden ve kâr amacı gütmeyen turizm işletmeleri, ulusal ve uluslararası turizm işletmeleri, özel, kamu ve karma turizm işletmeleri, doğrudan turizme bağlı işletmeler (birincil turizm işletmeleri) ve doğrudan turizme bağlı olmayan işletmeler (ikincil turizm işletmeleri) şeklindedir (Barutçugil, 1989, Güven, 1999; Kozak, 2010).

Gerek ulusal gerekse uluslararası turizm açısından ele alındığında, hizmeti sunan ve hizmeti alan arasındaki ilişkileri ve hizmeti alanların tatil tecrübelerinin olumlu bir şekilde tamamlanabilmesine etki eden birçok öğe bulunmaktadır. Örnek vermek gerekirse, paket tur satın alan bir turiste sunulan hizmetin olumlu bir şekilde tamamlanabilmesi için en az 100 farklı meslek 
grubunun etkin bir şekilde görevini sürdürmesi gerekmektedir. Acente görevlisi, sigorta görevlisi, pilot, hostes, gümrük memuru, şoför, tur rehberi gibi unsurların tümü turizm sisteminin birer halkasıdır (Kozak, Kozak ve Kozak, 2014).

Turizm bir sistem olarak düşünüldüğünde üç temel öğe ile karş1laş1lmaktadır (Kozak vd. 2014). Bunlar;

Turist gönderen destinasyon: $\mathrm{Bu}$ bölge, turizmin nerede başlayıp bittiğini ifade eden ve turistlerin sürekli ikamet ettikleri yeri tanımlamaktadır.

Ulaşım: Turistin, sürekli ikamet ettiği destinasyondan başka bir destinasyona gidip geri dönme aşamasında etkin olan ulaştırma araçlarını ve ulaşımı boyunca yaşadığı tecrübeleri kapsamaktadır.

Turist kabul eden destinasyon: Bu bölge, turistlerin tatil süreçleri boyunca tecrübe kazandıkları, bölgedeki yerel halkın "turist" olarak adlandırdığı ve istatistiksel evraklarda "turist" olarak geçtikleri destinasyondur.

Belirtilen bu süreçlerin gerçekleştirilmesi için seyahat acenteleri, tur operatörleri, ulaştırma, konaklama, yeme-içme ve eğlence gibi hizmetleri sunmakla yükümlü olan işletmelere ihtiyaç duyulmaktadır. Bu tür işletmeler ve bu işletmelerin yapmakla yükümlü olduğu hizmetler turizm sektöründeki bu sistemi destekleyen "yardımcı unsurlar" olarak belirtilmektedir (Kozak vd., 2014).

Ulaştırma işletmeleri, turistleri bulundukları bölgeden, turizm destinasyonuna ulaştırmakla yükümlü işletmelerdir. Bu işletmeler, karayolu, deniz yolu, hava yolu ve demir yolu olmak üzere kendi içerisinde dört gruba ayrılır (Özcan, 2018).

Konaklama işletmeleri, turistlere sürekli yaşadıkları kendi meskenlerinin dışına çeşitli sebeplerle yaptıkları seyahatleri boyunca konaklama, yeme-içme, eğlence vb. hizmetler sunan işletmelerdir (Şen, 2013). Turizm nedeniyle seyahat eden insanlara öncelikli olarak güvenli barınma hizmeti sunmak olmak üzere, konfor, dinlenme, yeme-içme, eğlence gibi ihtiyaçlarını da karşılayan bu işletmeler, kendi içerisinde oteller, moteller, tatil köyleri, pansiyonlar, dağ otelleri, termal tesisler gibi çeşitli gruplara ayrılmaktadır (Kozak, 2010: 129).

Yiyecek-içecek işletmeleri, turistlerin yapmış oldukları seyahatleri ve konaklama süreleri boyunca yeme-içme ihtiyaçlarını karşılamak için mal ve hizmet üreten ve sunan işletmelerdir. Bu işletmeler kendi içerisinde lüks restoranlar, kafeler/snack barlar, fastfood restoranlar ve yöresel restoranlar olarak ayrılmaktadır (Doğan, Şanlıer ve Tuncer, 2010).

Tur operatörleri ve seyahat acenteleri de turizm işletmeleri sınıfındadır. Tur operatörleri toptancılık mantığında çalışırlar ve paket tur gibi ürünleri oluştururlar. Seyahat acenteleri ise daha çok perakendecilik hizmeti sunan işletmelerdir (Kozak, 2010: 129). 


\section{Danışmanlık Hizmeti ve İhtiyaç Sebepleri}

Geçici bir süre ile bilgi, beceri ve tecrübesinden yararlanarak, işletmenin büyümesi ya da küçülmemesi için, işletmelerin problemlerini belirleyen, var olan problemler üzerine çalışan, bu sorunlara çözüm önerileri getiren ve işletme yöneticilerine bu önerileri ileten kişiye "danışman" denilmektedir (Aytar, 1999:16, Nural, 1991:45).

İş hayatının çoğu alanında danışmanlık hizmeti bulunmakta ve danışmanlık hizmetinin karşımıza en çok çıktığı kullanım alanları, işletme stratejilerini belirleme, iş planlaması yapma, finansal planlama ve kontrol, bilgi işlem sistemleri, ofis ve haberleşme sistemleri, üretime yönelik danışmanlık hizmeti, ücretlendirme sistemleri konusunda danışmanlık hizmeti, pazarlama ve üretim bakımından danışmanlık hizmetleri, insan kaynakları yönetiminde danışmanlık hizmetleri şeklinde sıralanabilir (Kayabaşı, 2009: 35, Tunalı, 2009:29, Kaynak, 2020:25).

- İşletme stratejilerini belirleme: Bir işletmenin orta ya da uzun dönemdeki stratejilerinin belirlenmesinde verilen bu hizmet, hammadde fiyatlarındaki artışta neler yapılabileceği, olas1 rekabet durumunda verilecek tepkiyi, yapılacak yeni yatırımların nereye ve ne zaman yapılacağı ve büyüme ve kar hedeflerinin belirlenmesi gibi konularda kullanılmaktadır. Bu konulara örnek olarak, fizibilite/ürün testleri, iş kurma ve geliştirme, satın alma ve şirket birleştirme gibi durumlar verilebilir.

- İş planlaması yapma: Bir işletmenin üretmesinde fayda görüleceği ürünü ve bu ürünü pazarlama yolları, bu üründen sağlanacak kar miktarını belirlemede verilen danışmanlık hizmetidir. Bir işletmenin pazarlama stratejisini uygulayabilmesi için bir pazarlama planına ihtiyacı vardır. Pazarlama planının temeli olan ürün, fiyat, yer ve promosyondan oluşan (4P) pazarlama karmasının kullanılması önerilmektedir Kotler, Bowen, Makens ve Balogu, 2017).

- Finansal planlama ve kontrol: İşletme yöneticilerine planlama ve kontrol sağlaması amacıyla bilgiler verilmesidir. Nakit akışı, ürün geliştirilmesi, üretim planlanması, bütçe planlanması ve tüm bu durumlar için gereken sistemlerin kurulmasında, uygulanmasında ve geliştirilmesinde tavsiyeler verilmesidir. Ayrıca finansal planlama bankacılık (tasarruf ve krediler, ticari bankalar, ipotek bankaları, kredi birliği), menkul kıymetler ve takas (aracı kurumlar, yatırım bankaları, yatırım danışmanı) ve uluslararası finans gibi konuları ele almaktadir (Muhammad, İbrahim, Bhatti ve Waqas, 2014).

- Bilgi işlem sistemleri: Bilgisayar ve elektronik altyapısına bağlı sistemlerin geliştirilmesi hizmetidir. $\mathrm{Bu}$ hizmette, bilgisayar sistemleri analizi, tasarımı ve mühendisliği, program geliştirme, kodlama, hata ayıklama uygulama konularında hizmetler verilmektedir (Kirby ve Dylan, 1997). 
- Ofis ve haberleşme sistemleri: İşletme dokümanlarının saklanmasına ve arşivlenmesine yardımcı olacak sistemlerin kurulmasına ve bu sistemlerin maliyetlerinin en düşük seviyeye indirilmesi konusunda ve işletme içerisindeki iletişim sisteminin sağlıklı bir şekilde işlemesi açısından verilen hizmettir.

- Üretime yönelik danışmanlık hizmeti: Yapılan pazar araştırması sonucunda satış tahminlerine göre hammadde temini, stokların ve üretimin planlanmasını ve kontrolü konusunda verilen hizmettir.

- Ücretlendirme sistemleri konusunda danışmanlık hizmetleri: İşletmede uygulanan ücret politikalarının belirlenmesi konusunda verilen hizmettir. Maliyetlerin düşürülmesi, maaş, prim, ikramiye, ödül sistemleri vb. sistemlerin oluşturulması, temel ücretler dışındaki sosyal yardımların belirlenmesi ve çalışanların performanslarını arttırmaya yönelik ücret sistemlerinin geliştirilmesi konusunda yardımcı olunmasıdır.

- Pazarlama ve üretim bakımından danışmanlık hizmetleri: İşletmelerin en önemli bölümlerinden olan pazarlama ve üretimde uluslararası pazar araştırması, satış tahminleri, reklam/promosyon, işletme imajı, üretim planlaması, müşteri karlılık araştırmaları, müşteri veri tabanı oluşturulması, ürün ve hizmetlerin fiyatlandırılması, pazarlama organizasyonu, depolama maliyetleri, stok yönetimi, yeni ürün oluşturma ve geliştirme, ekipman kullanımı gibi konularda verilen danışmanlık hizmetidir.

- İnsan kaynakları yönetiminde danışmanlık hizmetleri: Bir firmanın başarısı veya başarısızlığı, kısmen yönetimin çalışanlarının zamanını ve hizmetini satma ve aynı zamanda üretkenliklerini en üst düzeye çıkarma oranına bağlıdır (Yisa ve Edwards, 2002). Danışmanlık hizmetinin en çok kullanıldığı alan olan insan kaynaklarında, personel planlama, personel seçme ve yerleştirme, kariyer planlaması, iş değerleme ve ücret yönetimi, personellerin performans değerlendirilmesi, personelin eğitim ve motivasyonları konularında hizmet verilmektedir.

Yukarıda bahsedilen danışmanlık hizmetleri turizm işletmeleri de dâhil olmak üzere tüm işletmeler için ihtiyaç duyulmakta olan hizmetlerdir.

\section{Turizm Sektöründe Verilen Danışmanlık Hizmetleri}

Günümüz dünyasında danışmanlık, oldukça geniş bir alanı kapsayan bir sektör haline gelmiş̧ir. Bunları, pazarlama, üretim, satış, dış ticaret, pazar bulma, tarım, muhasebe, uzay çalışmaları, savunma, AR\&GE, ormancılık, bilgisayar, finans, gayrimenkul danışmanlığı, ekspertiz, hukuk, patent, telif hakları, fikri mülkiyet, vergi, insan kaynakları, mimarlık, peyzaj mimarisi faaliyetleri, enerji projelerine yönelik mühendislik, telekomünikasyon ve yayıncılık projeleri, çevre danışmanlığı, güvenlik danışmanlığı, istatistik, patent aracılığı, turist rehberliği, 
eğitimi, aile danışmanlığı ve diğer idari danışmanlık faaliyetleri oluşturmaktadır (Kılıç, 2020). Wilson (1972), işletmelerin danışmana ihtiyaç nedenlerini bazı sınıflandırmalara ayırmıştır. Bu sınıflandırmaları, belirli bir özel nedenle veya aralıklı olarak gerekli olan özel becerilere ihtiyaç, denetim gibi yasal zorunluluklar, sorunun nedenini belirlemek, nesnellik ve iç baskılardan kurtulma ihtiyacı, bazı özel kaynakların eksiklikleri, sektörler arası rekabet, yeni ürün geliştirme, yönetici araştırması ve satın almadaki ihtiyaçlar olarak ifade etmiştir (Wilson, 1972). Danışman ihtiyacının yaygın sebeplerinden birisi de hem sınırlı sayıdaki personeli hem de kurum içindeki yetenekleri tamamlamaktır (Mitchell, 1994).

Tablo 1.'de turizm sektöründe danışmanlık hizmeti veren bazı firmaların internet sitelerinden elde edilen bilgiler doğrultusunda turizm işletmelerine verilen danışmanlık hizmetleri listelenmiştir.

Tablo 1: Turizm İşletmelerine Verilen Danışmanlık Hizmetleri

\begin{tabular}{|c|c|c|}
\hline No & Danışmanlık Hizmetleri & Hizmet Detayları \\
\hline 1 & Destinasyon Pazarlaması & $\begin{array}{l}\text { Stratejik halkla ilişkiler ve medya ilişkileri, dijital PR, marka } \\
\text { oluşturma, ulusal turizm kurulları ve özel sektör için tanıtım } \\
\text { kampanyaları, tasarım ve içerik (URL1) }\end{array}$ \\
\hline 2 & Yatırım Danışmanlığı & $\begin{array}{l}\text { Olabilirlik ve pazar araştırmaları, işletme şirketi ve marka } \\
\text { araştırması, işletme, franchise, kira ve teknik hizmet anlaşmaları, } \\
\text { tesis değerlemesi, üçüncü şahıs raporlarının yorumu (URL3) }\end{array}$ \\
\hline 3 & Varlık Yönetimi & $\begin{array}{l}\text { Yönetim ve işletme analizleri, kar-zarar tablosu değerlendirmeleri, } \\
\text { tesis satın alma ve satış desteği, işletme denetimi ve varlık } \\
\text { yönetimi, hukuki ihtilaf desteği, hakemlik görevi, gizli müşteri } \\
\text { programı (URL1) }\end{array}$ \\
\hline 4 & Otel İşletmeciliği/Yönetimi & $\begin{array}{l}\text { Açılış öncesi bütçe hazırlanması, üst düzey personel seçimi ve } \\
\text { personel bütçesi hazırlanması, tesis standartları ve işletme } \\
\text { kılavuzları hazırlanması, işletme bütçesi hazırlanması, bütçe, } \\
\text { raporlama, yönetim bilgi ve kontrol sistemleri kurulması (URL2) }\end{array}$ \\
\hline 5 & Satı̧̧ ve Pazarlama & $\begin{array}{l}\text { Satışları artırma çalışmaları, satış ve pazarlama yöntemlerinin } \\
\text { yorumlanması, satış ve pazarlama ekibinin denetlenmesi, tur } \\
\text { operatörü ve seyahat acenteleriyle ilişkilerin yürütülmesi, OTA } \\
\text { (Online Travel Agency) ile ilişkilerin yürütülmesi (URL1, URL2) }\end{array}$ \\
\hline 6 & Turizm Mevzuatı & $\begin{array}{l}\text { Turizm yatırım belgesi, turizm işletme belgesi, yatırım teşvikleri, } \\
\text { hibeler, Avrupa fonları, Turizm Bakanlığı ilişkileri, Ekonomi } \\
\text { Bakanlığı ilişkileri, SPK değerleme raporları (URL2) }\end{array}$ \\
\hline 7 & Hukuk & $\begin{array}{l}\text { Kira sözleşmesi değerlendirmeleri, yönetim anlaşması } \\
\text { görüşmeleri, sosyal güvenlik kurumu mevzuatı, alacak takip, } \\
\text { çeşitlendirme, birleşme, devralmalar ve ortak girişimler, planlama, } \\
\text { yatırım teşvik ve belgelendirme (URL4) }\end{array}$ \\
\hline 8 & Sosyal Medya Yönetimi & Sosyal medya analizi ve danışmanlığı, web tasarımı (URL5) \\
\hline 9 & Bilişim Sistemleri & $\begin{array}{l}\text { Bilişim teknolojileri ve yazılımlar, teknolojik gelişmeleri izleme } \\
\text { ve uygulama ve seçme, otomasyon hizmetleri, kişisel verilerin } \\
\text { güvenliği (KVKK), yönetim bilgi sistemi, otel teknolojileri } \\
\text { yönetim danışmanlığ (URL1, URL2, URL3, URL4) }\end{array}$ \\
\hline
\end{tabular}




\begin{tabular}{|c|c|c|}
\hline 10 & İş Sağlığ1 ve Güvenliği & $\begin{array}{l}\text { Hijyen, iş sağllğ ve güvenliği, işyeri güvenliği, salgın hastalıklar } \\
\text { ile mücadele ve ilgili eğitimler, standartların uygulanması ve } \\
\text { geliştirilmesi (URL3) }\end{array}$ \\
\hline 11 & İnsan Kaynakları & $\begin{array}{l}\text { Performans değerlendirme, mesleki eğitim, kişisel gelişim, çalışan } \\
\text { bağlılığı ve elde tutma, çalışan eğitimi, çalışanların kariyer } \\
\text { gelişimlerini yönetme, işgücü planlaması, çalışan işe alma, çalışan } \\
\text { memnuniyeti, iş ve performans değerlendirme, yönetici geliştirme, } \\
\text { personel seçimi, yerleştirilmesi ve kayıtları, yönetim dışı personel } \\
\text { için eğitim programları, çalışan hizmetleri ve faydaları, ücret ve } \\
\text { maaş yönetimi (URL1, URL2, URL4, URL5) }\end{array}$ \\
\hline 12 & $\begin{array}{l}\text { Yiyecek ve İçecek } \\
\text { Yönetimi }\end{array}$ & $\begin{array}{l}\text { Satış becerilerini geliştirme, servis ve mutfak personeli eğitimleri, } \\
\text { hijyen eğitimleri, menü planlama, konsept belirleme, dekorasyon, } \\
\text { personelin satış becerilerini artırma, maliyet kontrol, ziyafet ve } \\
\text { toplantı satış danışmanlığı, Mutfak ve depo yerleşim planı, } \\
\text { ergonomi (URL5) }\end{array}$ \\
\hline 13 & Finansal Yönetim & $\begin{array}{l}\text { Finansal raporlama, banka finansmanı, fon yaratma, borç yeniden } \\
\text { yapılandırması, nakit akışı, risk yönetimi, mali değerlendirme, } \\
\text { birleşme, devralmalar ve ortak girişimler, finans ve muhasebe, } \\
\text { genel muhasebe, maliyet muhasebesi, uzun vadeli finansal } \\
\text { planlama, kısa vadeli planlama, bütçeleme ve kontrol, kredi ve } \\
\text { tahsilat, sermaye yatırımı, gelir analizi, finansal bilgiler ve } \\
\text { raporlama, finansal planlama, değerlemeler, vergiler (URL1, } \\
\text { URL2, URL3, URL4, URL5) }\end{array}$ \\
\hline 14 & $\begin{array}{l}\text { Mimari Tasarım } \\
\text { Projelendirme }\end{array}$ & $\begin{array}{l}\text { Proje bilgilendirme toplantıları, proje aşamalarının } \\
\text { koordinasyonu, statik, mekanik, elektrik, peyzaj, iç mekân } \\
\text { tasarımı belirlenmesi ve sözleşmelerinin hazırlanması (URL2) }\end{array}$ \\
\hline
\end{tabular}

\section{Yöntem}

$\mathrm{Bu}$ çalışmada, turizm işletme sahiplerinin/yöneticilerinin turizm sektörüne yatırım kararı verdikten önceki ve sonraki süreçlerde hangi danışmanlık hizmetlerine ihtiyaç duyduklarının belirlenmesi ve bu konudaki eksik yönlerin saptanması hedeflenmiştir. Ayrıca eksikliklerin giderilmesi konusunda hem turizm işletmeleri hem de danışmanlık firmalarının çalışmalarına katkı sunulması amaçlanmıştır. $\mathrm{Bu}$ çalışma, hem turizm işletmelerinde hem de danışmanlık hizmetlerinde farkındalık oluşturulması ve bundan sonraki çalışmalara fayda sağlaması yönünden önem arz etmektedir. Ayrıca bu konudaki çalışmalar incelendiğinde çok az sayıda kaynağa ulaşıldığı için bu çalışmanın literatüre katkı sağlayacağı düşünülmektedir.

Kastamonu ili kent merkezinde bulunan turizm işletmelerinin sahiplerine ve/veya yöneticilerine yönelik yapılan bu araştırma, nitel bir araştırmadır. Nitel araştırma yöntemi, turizm işletmelerinin ihtiyaç duyduğu danışmanlık hizmetlerini ortaya çıkarmak ve turizm işletmelerinin sahiplerinin/yöneticilerinin bu konuda bilgi ve görüşlerini derinlemesine incelemek amaciyla seçilmiştir. Nitel araştırma; gözlem, görüşme ve doküman analizi gibi nitel veri toplama tekniklerinin kullanıldığı, algıların ve olayların doğal ortamda gerçekçi ve bütüncül bir biçimde ortaya konmasına yönelik nitel bir sürecin izlendiği bir araştırma şeklidir (Yıldırım ve Şimşek, 
2005). Bu doğrultuda nitel olarak yapılan bu çalışmada; Kastamonu ilindeki turizm işletmelerinin bu sektöre yatırım yapma kararı öncesinde, yatırım sürecinde ve yatırım yaptıktan sonraki süreçlerde ne gibi araştırmalar yaptıkları, bu süreçte karşılaştıkları sorunları nasıl aştıkları ve herhangi bir danışmana ihtiyaç duyup duymadıkları gibi konular mülakat tekniği kullanılarak tespit edilmeye çalışılmıştır.

Araştırmanın evrenini turizm sektöründe aktif olarak hizmet sunan Kastamonu ili kent merkezindeki turizm işletmeleri oluşturmaktadır. Daha ulaşılabilir olabilmesi için yeme-içme ve/veya konaklama alanında hizmet sunan 12 turizm işletmesi araştırmanın örneklemini oluşturmaktadır. Kastamonu ili kent merkezinde yeme-içme ve/veya konaklama alanında hizmet sunan 17 turizm işletmesi saptanmış ancak beş turizm işletmesi ile tüm çabalara rağmen görüşülememiş ve araştırmaya 12 turizm işletmesi dâhil edilmiştir. Turizm işletmelerinin sahipleri ve/veya yöneticileriyle görüşme yapılmadan önce telefon aracılığıyla randevular alınmış ve görüşmeler yüz yüze gerçekleştirilmiştir.

Betimsel analiz tekniği, görüşülen kişi/kişilerden elde edilmiş verilerin özetlenerek yorumlandığı, görüşülenlerin düşüncelerini çarpıcı bir şekilde yansıtmak amacıyla doğrudan alıntıların kullanıldığı ve elde edilen sonuçların neden-sonuç ilişkisine göre yorumlandığı analiz tekniğidir (Yıldırım ve Şimşek, 2005). Uygulanan görüşme formu iki bölümden oluşmaktadır. Birinci bölümde katılımcıların demografik bilgilerine yönelik sorular, ikinci bölümde ise katılımcıların turizm sektörüne yatırım süreçlerinde ihtiyaç duyduğu danışmanlık hizmetlerine yönelik sorular yer almaktadır. Verilerin analizinde betimsel analiz tekniği kullanılmıştır.

\section{Bulgular}

Katılımcılara 7 soru yöneltilerek turizm sektörüne yatırım süreçlerinden önceki ve sonraki dönemlerde hangi danışmanlık hizmetlerine ihtiyaç duydukları konusunda görüşleri alınmıştır. Sorular hazırlanırken, Tunçsiper ve İlban (2006)'ın “Turizm İşletme Belgeli Otel İşletmelerinin Pazarlama Sorunları: Balıkesir İlinde Bir Alan Araştırması” adlı çalışmalarından, Bildirgen (2010)' in “İşletmelerin Danışman Kullanma Eğilimlerinin Belirlenmesi ve Danışman Seçiminde İzledikleri Yöntemler” adlı çalışmasından, Emir, Pelit ve Günay (2010)'ın “Üniversite Mezunu Çalışanların Bakış Açısıyla Otel İşletmelerinin Sorunları: Antalya'daki 5 Yıldızlı Otel İşletmelerinde Bir Uygulama” adlı çalışmalarından, Özcan (2018)'ın “Termal Turizm İşletmeleri ile Diğer Konaklama İşletmelerinin Maliyet Yönetimi Açısından Değerlendirilmesi: Çanakkale Örneği” adlı çalışmasından ve Aktürk (2019)'ün “Hizmet Sektöründe İşletme Sermayesi İhtiyacı: Turizm Sektöründe Bir Araştırma” adlı çalışmasından yararlanılmıştır. Katılımcılara yöneltilen sorular şu şekildedir;

1. Turizm sektörüne yatırım yapmaya nasıl karar verdiniz? Bu konuda yardım aldığınız kurum ve kuruluş var mı? 
2. Yatırım kararınızı verdikten sonra ne gibi araştırmalar yaptınız? Hangi konularda danışmanlık hizmetine ihtiyaç duydunuz?

3. Yatırım sürecinde ne gibi engel ya da zorluklarla karşılaştınız? Bu sorunları nasıl aştınız?

4. Pazarlama faaliyetleriniz nelerdir? Web siteniz üzerinden satış yapıyor musunuz?

5. Teknolojik hayata uyum dereceniz nedir? Dijital pazarlamanın hangi araçlarından faydalaniyorsunuz?

6. Kastamonu' daki turizm işletmelerinin kalitesini hangi düzeyde görüyorsunuz?

7. Kastamonu'nun turizm sektöründe büyümesi için yapılması gerekenler sizce nelerdir?

Yukarıda belirtilen sorulardan elde edilen bulgular, betimsel analiz tekniği ile analiz edilip, bazı ifadelere yönelik dağılımlar tablolara aktarılmıştır. Görüşmelerden elde edilen verilere ilişkin ifadeler araştırmaya katılan işletme sahiplerinin/yöneticilerinin belirttiği şekilde verilmiştir. İlk olarak katılımcıların demografik özellikleri Tablo 2'de ifade edilmiştir.

Tablo 2: Katılımcıların Demografik Bilgileri

\begin{tabular}{|l|l|l|l|l|l|l|r|}
\hline & & & & & & \\
\end{tabular}




\begin{tabular}{|l|l|l|l|l|l|l|l|l|}
\hline K11 & Erkek & 50 & Ortaokul & Evli & 6 yıl & Konaklama & İşletme Sahibi & Hayır \\
\hline K12 & Kadın & 33 & Lisans & Bekar & 13 yıl & Konaklama & Otel Müdürü & $\begin{array}{l}\text { Evet } \\
\text { (Turizm ve } \\
\text { Otel İssl. } \\
\text { Lisans) }\end{array}$ \\
\hline
\end{tabular}

Yukarıdaki tabloda yer alan bilgilere göre katılımcıların \%75'i erkek, \%25'i de kadınlardan oluşmaktadır. Katılımcılar 24 ile 66 yaş aralığındadırlar. Eğitim durumları göz önüne alındığında katılımcıların \%41,7'sinin lisans, \%33,3’ünün lise, \%8,3'ünün lisansüstü, \%8,3'ünün ilkokul ve \%8,3'ünün de ortaokul eğitimleri aldığı görülmektedir. Katılımcıların \%66,7'si evli, geriye kalan \%33,3’ü de bekardır. Mesleki tecrübeleri 1 yıl ile 36 yıl arasındadır. İşletme türlerine bakıldığında işletmelerin \%66,7'si konaklama, \%33,3'ü ise yeme-içme işletmesi olarak ön plana çıkmaktadır. Görüşme yapılan katılımcıların \%75'i işletme sahibi, \%16,6'sı genel müdür ve \%8,3'ü de otel müdürüdür. Turizm ve/veya otel işletmeciliği hakkında eğitim aldınız mı sorusuna katılımcıların \%50'si hayır cevabını verirken, geriye kalan \%50'si ise evet cevabını vermiştir. Bu soruya evet cevabını verenlerin \%50'si turizm konusunda en az lisans derecesinde eğitim alırken, diğer \%50 ise özel kurumlardan eğitim aldıklarını dile getirmişlerdir

Katılımcılara "Turizm sektörüne yatırım yapmaya nasıl karar verdiniz? Bu konuda yardım aldığınız kurum ve kuruluş var mı?” sorusu yöneltilmiş ve verilen bazı cevaplar şu şekildedir;

"Kar marjı yüksek olduğu için bu sektöre girdim. Kimseden yardım almadık." (K1)

"Birikmiş sermayemiz vard, elimize de bu işletme gibi bir firsat geçince ani bir şekilde bu sektöre girdik. Hiçbir kurumdan yardım almadık.” (K6)

"Kastamonu'nun bu alanda eksik olduğunu düşündüğ̈̈m ve bu açı̆̆ı kendi lehime kullanmak istediğim için bu sektöre girdim. Yardım almadım." (K10)

"Aslında inşaat sektöründeyiz. Bu yatırımı bir ekstra kazanç olarak düşündük ve getirisinin fazla olduğunu hesapladık. Bu yüzden bu sektöre girdik. Hiçbir kuruluştan yardım almadik" (K12)

Katılımcıların cevapları incelendiğinde işletmeler hiçbir kurum ve kuruluştan yardım almamış ve yatırım kararlarında farklı düşünceler belirtmişlerdir. Buna göre de aşağıdaki tablo şekillenmiştir.

Tablo 3: Turizm sektörüne yatırımdaki ana sebepler

\begin{tabular}{|l|l|}
\hline Yatırım Kararındaki Ana Sebepler & Katılımcılar \\
\hline Kar marj1 yüksek & $\mathrm{K} 1, \mathrm{~K} 8, \mathrm{~K} 10, \mathrm{~K} 12$ \\
\hline Kastamonu turizm potansiyeli & $\mathrm{K} 7$ \\
\hline Aynı sektördeki aile işletmesi & $\mathrm{K} 2, \mathrm{~K} 3$ \\
\hline Yöreye özgü bir ürünü ön plana çıkarma & $\mathrm{K} 5$ \\
\hline Doğaçlama bir şekilde & $\mathrm{K} 6$, \\
\hline Öncesinde yapılan mesleğin katkıları & $\mathrm{K} 4, \mathrm{~K} 9$ \\
\hline Kastamonu'daki eksiklik & $\mathrm{K} 7, \mathrm{~K} 10, \mathrm{~K} 11$ \\
\hline
\end{tabular}

İşletme sahiplerinin/yöneticilerinin turizm sektörüne yatırım yapma sebeplerinin en başında turizm işletmesinin kar marjının yüksek olduğu düşüncesi gelmektedir. Bunun dışında 
işletme binasının kendilerine ait olduğu için ve daha öncesinde de turizm işletmesi olarak kullanıldığı için bu sektörde devam etme kararları alındığı görülmektedir. 2 katılımcı daha önceki yaptıkları işlerinden dolayı böyle bir yatırım yaptığını belirtirken, 1 katılımcı da birikmiş sermayesini ani bir kararla bu sektöre yatırmaya karar verdiğini belirtmiştir.

Katılımcılara "Yatırım kararınızı verdikten sonra ne gibi araştırmalar yaptınız? Hangi konularda danışmanlık hizmetine ihtiyaç duydunuz?” sorusu yöneltilmiş ve bazı katılımcı cevapları aşağıda belirtilmiştir.

"İ̧letmemizi müşterilere nasıl duyuracağımıza yönelik araştırmalar yaptık. Herhangi bir danışmanlık hizmetine ihtiyaç duymadık." (K1)

"Otel ve restoran işletmeciliği hakkında bazı araştırmalar yaptık ve bu konularda da danışmanlık hizmeti aldık." (K2)

"Mesleki tecrübeme güvendiğim için araştırma yapmadım. Danışmanlık hizmetine de ihtiyaç duymadım." (K4)

“Öncelikle bir iş planı hazırladık. Kastamonu'nun en önemli unsurunun tarih olduğunu anladığımızda tarihi mekanların işletmelere dönüşürü̈lmesi fikrinin daha uygun olduğunu gördük. Bu konularla ilgili danışmana ihtiyacımız oldu ancak işletmeyi kendimizce restore ettik." (K7)

“Kastamonu'daki turizm potansiyeli konusunda araştırmalar yaptık. Kastamonu'daki turizm alanlarında yapılan toplantıları, çalışmaları vb. inceledik. Danışmana ihtiyaç duymadan kendimiz araştırdık." (K12)

Katılımcıların verdikleri cevaplara göre aşağıdaki tablo şekillenmiştir.

Tablo 4: Yatırım kararı sonrası yapılan araştırmalar

\begin{tabular}{|l|l|}
\hline Yatırım Kararı Sonrası Yapılan Araştırmalar & \multicolumn{1}{c|}{ Katılımcılar } \\
\hline Pazar Araştırması & $\mathrm{K} 1, \mathrm{~K} 2, \mathrm{~K} 3, \mathrm{~K} 5, \mathrm{~K} 6, \mathrm{~K} 7, \mathrm{~K} 9, \mathrm{~K} 10, \mathrm{~K} 12$ \\
\hline Araştırma ihtiyacı hissetmeyen & $\mathrm{K} 4, \mathrm{~K} 8, \mathrm{~K} 11$, \\
\hline Danışman ihtiyacı hisseden & $\mathrm{K} 2, \mathrm{~K} 5, \mathrm{~K} 7$, \\
\hline
\end{tabular}

Tablo 4'teki işletme sahiplerinin/yöneticilerin verdikleri cevaplara göre 12 katılımcıdan yalnızca 3 tanesi danışmanlık hizmetine ihtiyaç duyduklarını belirtirken diğer 9 katılımcı herhangi bir konuda danışmana ihtiyaç duymadıklarını ve araştırmaları kendileri ve yakın çevresiyle birlikle yaptıklarını belirtmişlerdir. Yapılan araştırmalara bakıldığında da, müşterilere ulaşım, aynı sektördeki diğer işletmelerle kıyaslamalar, açılacak işletmenin konumu, yöresel yemeklerin yapılışı, otel ve restoran işletmeciliği ve Kastamonu'nun turizm potansiyeli gibi konularda araştırmalar yapıldığı görülmektedir. 2 katılımcı ise mesleki tecrübelerine güvenerek ve sektör hakkında yeterli bilgiye sahip olduğunu düşündüğü için danışmana ihtiyaç duymadığını belirtmiştir.

Katılımcılara "Yatırım sürecinde ne gibi engel ya da zorluklarla karşılaştınız? Bu sorunları nasıl aştınız?" şeklinde bir soru yöneltilmiştir ve katılımcıların verdikleri bazı cevaplar şu şekildedir; 
"Hiçbir zorluk yaşamadık, her şey planladı̆̆ımız gibi gitti. Çevremiz de geniş olduğu için sorun yaşamadık." (K1)

"Tarihi bir yapıyı yeniden canlandırmak için oldukça fazla sermaye gerekti. Planladığımız dışında çok büyük paralar ödedik. Birikimimiz ve sabrımızın sonucunda bu sorunları aşabildik." (K3)

"Bürokratik olarak zorlukla karşılaştık. Gerekli belgeleri vermek için bizden özel isteklerde bulundular. Biz de mecburen vermek zorunda kaldık. Planladığımız üzerinde para harcadik." (K10)

"Herhangi bir zorlukla karşılaşılmadı. Bu tür işletmeleri Kastamonu'da açmak çok kolay." (K12)

Katılımcıların verdikleri cevaplara göre aşağıdaki tablo oluşmuştur.

Tablo 5: Yatırım sürecinde karşılaşılan zorluklar

\begin{tabular}{|l|l|}
\hline \multicolumn{1}{|c|}{ Yatırım Sürecinde Karşılaşılan Zorluklar } & \multicolumn{1}{c|}{ Katılımcılar } \\
\hline Maddi zorluklar & $\mathrm{K} 3, \mathrm{~K} 4, \mathrm{~K} 10$, \\
\hline Nitelikli personel sorunu & $\mathrm{K} 2, \mathrm{~K} 5, \mathrm{~K} 7$, \\
\hline Potansiyel müşterilere ulaşım & $\mathrm{K} 6, \mathrm{~K} 9$, \\
\hline Sorun yaşamayanlar & $\mathrm{K} 1, \mathrm{~K} 8, \mathrm{~K} 11, \mathrm{~K} 12$, \\
\hline
\end{tabular}

Katılımcıların cevapları incelendiğinde 4 işletmenin sahibi/yöneticisi herhangi bir engel ya da zorlukla karşılaşılmadığını, tüm işlemlerin sürece uygun bir şekilde ilerlediğini belirtirken, geriye kalan 8 işletmenin sahibi/yöneticisi ise farklı konularda sorunlarla ve zorluklarla karşılaştıklarını belirtmişlerdir. 3 işletme bu süreçte işletmenin dekorasyonu, mimarisi gibi konularda nitelikli personel bulmada sorun yaşadıklarını, bu sorunları da ancak birden fazla firma ile görüşerek ya da kendileri de işin içerisine dahil olarak aşabildiklerini belirtmişlerdir. 2 işletme sahibi/yöneticisi ise bu süreçte maddi zorluklar yaşadıklarını, planladıkları giderlerden daha fazla harcama yaptıklarını ve bu durumu da bankadan kredi çekerek ve/veya birikimlerinden yararlanarak aştıklarını belirtmişlerdir. Yalnızca 1 işletme bürokratik engel ile karşılaştığını ifade etmiştir. Bir diğer işletme de potansiyel müşterilere ulaşım konusunda sorunlar yaşadığını belirtmiştir.

Katılımcılara "Pazarlama faaliyetleriniz nelerdir? Web siteniz üzerinden satış yapıyor musunuz?” şeklinde bir soru sorulmuş ve bazı katılımcılar cevaplarını şu şekilde belirtmişlerdir;

"Sosyal medya yoluyla pazarlama yaplyoruz. Yerel basinda, radyoda reklamlar veriyoruz. Broşür bastırlyoruz, fuarlara gidiyoruz. Acentelerle işbirliği içindeyiz. Web'den satış yapıyoruz." (K3)

"Kendi imkanlarımızla tanıtım yapıyoruz. İnternetten satış yapmıyoruz. Broşür vb. şeyler bastırmadık. Kendi çevremizi kullaniyoruz." (K6)

"Sosyal medyayı tanitım ve pazarlamada kullanmaktayı. Alaninda uzman pazarlamacı personellerle çalışmaktayız. Televizyonda ve YouTube'de reklam çalışmaları yapıyoruz. Webden satışımız var. Acentelerle de çalışlyoruz." (K7)

"Webden satıs yapıyoruz. Acentelerle çalışıyoruz. Kastamonu'daki kurumsal firmaları ziyaret ederek tanitım çalışmaları yapıyoruz." (K10)

"İnşaat firmalarıyla çalışlyoruz. İhaleleri inceleyerek firmalara ulaşıyoruz. Acentelerle de çalışıyoruz. Webden satışımız yok." (K12) 
İşletme sahiplerinin/yöneticilerinin vermiş olduğu cevaplara göre çalışma kapsamındaki 12 işletmenin 7'si internet adresleri üzerinden satış yaptıklarını belirtirken, geriye kalan 5 işletme ise internet adreslerinden satış yapmadıklarını belirtmişlerdir. Satış ve pazarlama konusunda, 7 turizm işletmesi acenteler yoluyla müşterilere ulaşırken, diğer 5 işletme acenteler ile birlikte çalışmadıklarını belirtmişlerdir. Günümüzde pazarlamanın önemli bir parçası haline gelen sosyal medya kanallarını ise 8 işletme aktif bir şekilde kullandıklarını belirtirken, diğer 4 işletme, sosyal medyadan yararlanmadığını ifade etmiştir. Bu işletmeler, yakın çevrelerini kullanarak, kurumsal firmalarla iletişime geçerek ya da yalnızca acenteler aracılığıyla satış yaptıklarını belirtmişlerdir. Buna göre aşağıdaki tablo şekillenmiştir.

Tablo 6: İşletmelerin pazarlama faaliyetleri

\begin{tabular}{|l|l|}
\hline \multicolumn{1}{|c|}{ Pazarlama Faaliyetleri } & \multicolumn{1}{c|}{ Katılımcılar } \\
\hline Sosyal medya aracılığıyla & $\mathrm{K} 1, \mathrm{~K} 2, \mathrm{~K} 3, \mathrm{~K} 4, \mathrm{~K} 5, \mathrm{~K} 7, \mathrm{~K} 8, \mathrm{~K} 9$ \\
\hline Acenteler aracılı̆̆ılyla & $\mathrm{K} 1, \mathrm{~K} 2, \mathrm{~K} 3, \mathrm{~K} 4, \mathrm{~K} 7, \mathrm{~K} 10, \mathrm{~K} 11, \mathrm{~K} 12$ \\
\hline Broşür, afiş vb. aracılığıyla & $\mathrm{K} 1, \mathrm{~K} 3, \mathrm{~K} 6$ \\
\hline Televizyon, radyo vb. aracıı̆ı̆̆yla & $\mathrm{K} 3, \mathrm{~K} 5, \mathrm{~K} 7$ \\
\hline Web sitesi aracılığıyla & $\mathrm{K} 1, \mathrm{~K} 2, \mathrm{~K} 3, \mathrm{~K} 5, \mathrm{~K} 7, \mathrm{~K} 8, \mathrm{~K} 10$ \\
\hline Diğer & $\mathrm{K} 3, \mathrm{~K} 4, \mathrm{~K} 6, \mathrm{~K} 10, \mathrm{~K} 12$ \\
\hline
\end{tabular}

Katılımcılara "Teknolojik hayata uyum dereceniz nedir? Dijital pazarlamanın hangi araçlarından faydalanıyorsunuz?" sorusu yöneltilmiştir. Bazı katılımcıların cevapları şu şekildedir;

"Uyum derecemiz teknolojinin gelişme düzeyine göre değişiyor. Facebook, Instagram'dan yararlaniyoruz." (K2)

"Teknoloji ile yakından ilgiliyiz. Sosyal medyanın neredeyse tüm mecralarını aktifolarak kullanmaktayzz." (K8)

"Son çıkan gelişmeleri takip ederek uyum gösteriyoruz. Sosyal medyayı aktif kullanamıyoruz. Çünkü bu iş için fazladan birini çalıştırmak istemedik. İş yükü azalsın istedik ancak ekonomik olarak mümkün değil." (K10)

"Sosyal medya yoluyla pazarlama. Instagram, Facebook ve Google aracılĭgryla pazarlamalar yapıyoruz." (K12)

Katılımcıların cevapları incelendiğinde 4 işletme sahibi/yöneticisi dijital pazarlama konusunda Google arama motorunu kullandıklarını ifade etmişlerdir. K10 ve K11 dışındaki tüm katılımcılar dijital pazarlama yöntemlerini sosyal medya kanalları ile kullandıklarını söylemişlerdir. Teknolojik hayata uyum dereceleri hakkında ise tüm katılımcılar son gelişmeleri takip etmeye çalıştıklarını ve ellerinden geldiğince bu sistemleri kullanmayı denediklerini belirtmişlerdir. Bu cevaplara göre aşağıdaki tablo şekillenmiştir.

Tablo 7: Dijital pazarlama araçları

\begin{tabular}{|l|l|}
\hline \multicolumn{1}{|c|}{ Dijital pazarlama aracı } & \multicolumn{1}{c|}{ Katılımcılar } \\
\hline Sosyal Medya (Facebook, İnstagram vb.) & $\mathrm{K} 1, \mathrm{~K} 2, \mathrm{~K} 3, \mathrm{~K} 4, \mathrm{~K} 5, \mathrm{~K} 6, \mathrm{~K} 7, \mathrm{~K} 8, \mathrm{~K} 9, \mathrm{~K} 11, \mathrm{~K} 12$ \\
\hline İşletmeye ait web sayfas1 & $\mathrm{K} 3, \mathrm{~K} 4, \mathrm{~K} 5$, \\
\hline Google & $\mathrm{K} 1, \mathrm{~K} 3, \mathrm{~K} 4, \mathrm{~K} 6, \mathrm{~K} 12$, \\
\hline
\end{tabular}


Bazı katılımcıların "Kastamonu'daki turizm işletmelerinin kalitesini hangi düzeyde görüyorsunuz?" sorusuna verdikleri cevaplar şu şekildedir;

"Personel konusundaki sorunlardan ve tüm işletmelerin aç gözlü olmalarından dolayı kalite düşüktür. Yöresellikten çıtktkları için kalitelerini kaybediyorlar." (K1)

"Kastamonu'da müşteriler çok fazla sorun yaşadıklarını söylerler. Temizlik, personel anlamında çok şikayetçiler. Işsletmeler de bu sorunu gidermek için çaba göstermiyor." (K3)

"Kastamonu'daki tesislerin restorasyon süreçlerindeki sorunlar ve kendilerini yenilemediklerinden dolayı turizm kalitesi \%50'lerdedir. Ancak Kastamonu turizmle tanıştıkça bu düzey daha da artacaktır." (K7)

"Zaylf görüyorum. Turizmi bilmiyorlar Hem kendilerinin hem de çalışanlarının yerine işi bilen birileri gelmelidir." (K9)

"Birkaç işletme dişında hepsi düşük seviyede. Reklam yapılmıyor, turlara yoğunlaşılmıyor. Kapıdan girene satış yapma mantığıyla ilerliyorlar.” (K12)

Katılımcıların verdikleri cevaplara göre aşağıdaki tablo şekillenmiştir.

Tablo 8: Turizm işletmelerindeki şikayetler

\begin{tabular}{|l|l|}
\hline \multicolumn{1}{|c|}{ Şikayetçi Olunan Durum } & \multicolumn{2}{c|}{ Katılımclar } \\
\hline Personel sorunu & $\mathrm{K} 1, \mathrm{~K} 3, \mathrm{~K} 9$ \\
\hline Yöresellikten uzaklaşma & $\mathrm{K} 1, \mathrm{~K} 5, \mathrm{~K} 6$ \\
\hline Bilgi yetersizliği & $\mathrm{K} 7, \mathrm{~K} 8, \mathrm{~K} 9, \mathrm{~K} 10, \mathrm{~K} 12$ \\
\hline Daha fazla kazanma isteği & $\mathrm{K} 1, \mathrm{~K} 6$ \\
\hline Kalite düzeyi yeterli & $\mathrm{K} 2, \mathrm{~K} 4, \mathrm{~K} 11$ \\
\hline
\end{tabular}

Yukarıdaki tabloya göre 3 işletme sahibi/yöneticisi, diğer işletmelerin durumunu yeterli/orta düzeyde görürken geriye kalan 9 işletme sahibi/yöneticisi ise Kastamonu'daki turizm işletmelerinin kalite düzeyinin düşük olduğunu belirtmiştir. Bu düşük kaliteyi, nitelikli personel çalıştırmadıkları, yöresellik çerçevesinde açılıp daha sonra yöresellikten çıktıkları, işletmelerin yeniliğe kapalı oldukları, işletme sahipleri ve çalışanlarının turizm konusunda yetersiz oldukları vb. konulara bağlamaktadırlar.

Katılımcılara "Kastamonu'da turizm sektöründe büyümesi için yapılması gerekenler sizce nelerdir? sorusu yöneltilmiş ve bazı katılımcı cevapları aşağıda belirtilmiştir.

“... Kastamonu halkı bilinçlendirilmeli. Belediyenin işletme sahipleriyle iletişimi artmalı ve birlikte karar alınmalıdır. Ulusal basında yer almak için daha fazla tanıtım yapılmalıdır. Otopark sorunu çözülmelidir. Şehre gelen turist kafilesinin rotası genişletilmelidir. ... “(K1)

“... Kastamonu halkı turistik değerler konusunda bilinçlendirilmeli. ... Otopark sorunu çözülmeli, müşterilerin en çok sorduğu soru "Otoparkını var mı?” sorusu oluyor. Belediye, turizme yeterli önemi vermeli. Çevre düzenlemeleri yapılmall, turistik binalar restore edilmeli. Çevre illerle etkileşime geçilmelidir. Ulusal basında yer almak için önemli bütçe ayrllmall. Belediye ve Valilik birlikte hareket etmeli. Turistlerin zaman geçirebilecekleri, eğlenebilecekleri mekânlar yapılmalı. ... "(K3)

“... Yerel yöneticiler ve Sivil Toplum Kuruluşları bir araya gelip işletmecilerle iletişim halinde çalışmalıdır. İnsanlar turizm sektörünü bilmiyorlar, turizm öğretilmelidir. Yatılı 
turistlere yönelik imkânlar geliştirilmeli. Turistlerin ilgisini çeken mekânların gelişimi için çalışmalar yapılmalıdır. Alkollü mekânlar, gece hayatı gibi aktiviteler yapılmalıdır." (K6)

"Kastamonu insaninin turizme adapte olmasl gerekiyor. Vasifl turizm elemanlarının yetiştirilmesi gerekiyor. Tanıtım ve reklam çalışmalarına daha fazla önem verilmeli." (K7)

"Şehrin yöneticilerinin hepsinin turizmin nasıl bir güç olduğunun farkına varması gerekir. Ayrıca hepsinin ortak bir fikirde buluşması gerekir. Turizm sektöründe çalışanlar işini zorla değil de severek yapmalıdır. Nitelikli personel yetiștirilmelidir." (K11)

"Belediye yeterince önem verip yarım kalmış turizm projeleri bitirmelidir. Il Kültür Müdürlügü yeteri kadar çalışmalıdır. Kastamonu esnafi fuar, tanıtım vb. organizasyonlara katılım sağlamalı. Kastamonu, geçiş güzergâhı olmaktan çıkarılmalı. Kastamonu halkı turizm konusunda bilinçlendirilmeli. Turistlere "para" gözüyle değil de "misafir" gözüyle bakılmall. Otopark sorunu çözülmeli. ..." (K12)

Katılımcılar Kastamonu'nun turizm sektöründe gelişmesi için yapılması gerekenlerin saymakla bitmeyeceğini, bu tür işlemlerin yıllardır yapılmadığını vurgulamışlardır. Çalışma kapsamındaki 12 işletmenin sahibi de bu konuda aynı çalışmaları belirtmişlerdir. Buna göre de aşağıdaki tablo şekillenmiştir.

Tablo 9: Kastamonu'nun turizm sektöründe gelişmesi için yapılması gerekenler

\begin{tabular}{|l|l|}
\hline \multicolumn{1}{|c|}{ Kastamonu'da Yapılması Gerekenler } & \multicolumn{1}{c|}{ Katılımcılar } \\
\hline Tanıtım yapılmalı & $\mathrm{K} 1, \mathrm{~K} 2, \mathrm{~K} 3, \mathrm{~K} 4, \mathrm{~K} 5, \mathrm{~K} 7, \mathrm{~K} 8, \mathrm{~K} 10, \mathrm{~K} 12$ \\
\hline Yerel halk bilinçlendirilmeli & $\mathrm{K} 1, \mathrm{~K} 2, \mathrm{~K} 3, \mathrm{~K} 5, \mathrm{~K} 6, \mathrm{~K} 7, \mathrm{~K} 9, \mathrm{~K} 10, \mathrm{~K} 12$ \\
\hline Yerel yöneticiler turizme önem vermeli & $\mathrm{K} 1, \mathrm{~K} 3, \mathrm{~K} 6, \mathrm{~K} 9, \mathrm{~K} 10, \mathrm{~K} 11, \mathrm{~K} 12$ \\
\hline Otopark sorunu çözülmeli & $\mathrm{K} 1, \mathrm{~K} 3, \mathrm{~K} 5, \mathrm{~K} 12$ \\
\hline Çevre düzenlemeleri yapılmalı & $\mathrm{K} 1, \mathrm{~K} 3, \mathrm{~K} 12$ \\
\hline Nitelikli personel istihdamı yapılmalı & $\mathrm{K} 7, \mathrm{~K} 11, \mathrm{~K} 12$ \\
\hline $\begin{array}{l}\text { Yerel yönetim, STK ve işletmeler birlikte hareket } \\
\text { etmeli }\end{array}$ & $\mathrm{K} 1, \mathrm{~K} 3, \mathrm{~K} 6, \mathrm{~K} 11$ \\
\hline Diğer & $\mathrm{K} 1, \mathrm{~K} 3, \mathrm{~K} 4, \mathrm{~K} 5, \mathrm{~K} 6, \mathrm{~K} 10, \mathrm{~K} 12$ \\
\hline
\end{tabular}

Yukarıdaki tablo incelendiğinde 12 işletmenin 9'u Kastamonu'daki tanıtım ve reklam çalışmalarının yetersiz olduğunu ve bu konunun önemli olduğunu belirtmişlerdir. Aynı şekilde 12 turizm işletmesinin 9'u Kastamonu yerel halkının turizm konusunda bilinçlendirilmesinin Kastamonu turizmini olumlu yönde etkileyeceğini ifade etmiştir. 7 turizm işletmesi, Kastamonu yerel yöneticilerinin turizm sektörüne gereken önemi vermediğini ve Kastamonu'nun turizm sektöründe büyümesi için gereken önemin verilmesi gerektiğini, 4 işletme Kastamonu ilinde otopark sorunu olduğunu ve bu durumun da turistlerin işletmeleri tercih etme durumlarını etkilediğini vurgulamıştır. 3 turizm işletmesi de çevre düzenlemeleri konusunda çalışmalar yapılmasını gerektiğini belirtmiştir. 4 turizm işletme sahibi/yöneticisi, turizm işletmeleri çalışanlarının turizm konusunda yetersiz olduklarını ve bu çalışanların yerine turizm konusunda nitelikli çalışanların işe alınması gerektiğini söylemiştir. 4 turizm işletme sahibi/yöneticisi Kastamonu'da turizmin gelişmesi için yerel yönetimler, sivil toplum kuruluşları ve işletmelerin birbirleriyle etkileşim halinde olmalarını, ortak kararlar vermeleri gerektiğini belirtmişlerdir. Bazı işletmeler bu görüşlere ek olarak, turist kafilelerinin rotalarının genişletilmesi, turistlere yönelik 
eğlence merkezleri yapılması, rehber sayısının arttırılması, çevre illerle ortak çalışmalar yapılması gibi önerilerde bulunmuşlardır.

\section{Sonuç ve Öneriler}

Sürekli bir değişim döngüsü içerisinde olduğumuz günümüz şartlarında, tüm sektörlerin başarılı bir şekilde faaliyetlerini sürdürebilmeleri için bu değişimlere uyum sağlamaları gerekmektedir. Her türlü olaydan kolaylıkla etkilenebilen bir sektör olan turizm sektöründe, yalnızca turistler değil aynı zamanda turistlere hizmet sunan işletmeler de bu olaylardan etkilenebilmektedir. $\mathrm{Bu}$ çalışmada, turizm işletmelerinin ihtiyaç duyduğu danışmanlık hizmetlerini öğrenmek ve ulaşılan sonuçlar neticesinde hem turizm işletmelerinde hem de danışmanlık hizmeti veren firmalarda farkındalık oluşturmak amaçlanmaktadır. Bu kapsamda hazırlanan görüşme formu çerçevesinde Kastamonu ili kent merkezindeki konaklama ve yemeiçme işletmelerinin sahipleri ve/veya yöneticilerinin görüşleri alınarak bu sektöre yatırım kararının öncesindeki ve sonrasındaki süreçlerde ihtiyaç duydukları danışmanlık hizmetleri belirlenmeye çalışılmıştır.

Elde edilen veriler 1şığında, katılımcıların çoğunluğu onları turizm sektörüne yatırım yapmaya iten nedenleri sektörün kar getirisinin yüksek oluşu ve Kastamonu ilinin bu sektördeki eksikliğidir. Ayrıca araştırmaya katılan işletmelerin hiçbiri bu süreçte herhangi bir kurum ve kuruluştan yardım almadıklarını belirtmişlerdir. $\mathrm{Bu}$ durumun başlıca nedeni işletme sahiplerindeki danışman algısının olmaması ya da zayıf olması olarak düşünülebilir. Bu konuda yapılması önerilen en önemli faaliyetlerden birisi, bu tür işletmelere danışmanlık hakkında detaylı bilgi verilmesi ve danışman kavramının aşılanmasıdır.

Danışmanlık hizmeti veren kurum ya da kuruluşların turizm işletmelerine yönelik sundukları hizmetler ve turizm işletmelerinin bu sektöre yatırım yaparken yaptıkları araştırma konuları paralellik göstermektedir. Hem turizm işletmeleri hem de danışmanlık hizmeti sunan kurum ya da kuruluşlar neredeyse aynı konuları araştırmaktadır. Bu konuda turizm işletme sahip/yöneticilerinin yapmaya çalıştıkları araştırmalar, profesyonel kişiler tarafından yapılarak daha verimli bir sonuca ulaşılmaktadır. Turizm işletmelerinin, araştırma kapsamlarını artırarak bu tür işlemlerin daha profesyonel bir şekilde yapıldığının farkına varmaları gerekmektedir. Bununla ilgili de yeni işletmelerin açılması hususunda söz ve yetki sahibi olan belediye, valilik vb. kurum ve kuruluşların, işletme sahiplerine bu konuda bilgilendirme çalışmaları yapılabilir.

Kastamonu ili kent merkezindeki turizm işletmelerinin çoğunluğunun danışmanlık hizmetine ihtiyaç duymadığ 1 görülmüştür. Danışmanlık hizmetine ihtiyaç duyan bazı işletmeler ise gerekli kurum ya da kuruluşlara rahatlıkla ulaşamadığını belirtmiştir. Bu konuda danışmanlık hizmeti veren firmaların, turizm işletmeleriyle daha fazla etkileşim haline geçmesi ve hizmetlerinden bahsederek gerekli bilgilendirmeleri yapmaları önerilmektedir. 
Katılımcılar, Kastamonu ili kent merkezindeki turizm işletmelerinin kalitelerinin düşük seviyede olduğu ve bu kalitesizliğin nedeninin hem personellerin hem de işletme yöneticilerinin turizm açısından yetersiz oldukları konusunda hemfikirdir. Bu konuyla ilgili turizm işletmesi sahiplerinin turizm konusunda bilgilendirilmesi ve çalışacak personellerin yalnızca turizm konusunda bilinçli kişilerden oluşması gibi zorunluluklar getirilmesi önerilmektedir.

Bir bölgedeki turizmin gelişmesi için hem yerli halkın hem de yerel yöneticilerin etkisi oldukça büyüktür. Kastamonu yerel yöneticileri ve yerel halkın turizm algılarını geliştirmek ve turizme gereken önemi verilmesi için turizm eğitimi gibi çalışmalar yapılmalıdır.

Çalışma kapsamındaki öneriler şu şekildedir;

- Turizm işletmesi sahiplerine, yöneticilerine ve personellerine turizm eğitimi/kursu verilebilir.

- Turizm işletmesi sahiplerine/yöneticilerine danışmanlık konusuyla ilgili bilgiler verilebilir ve profesyonel firmalara yönlendirilmeleri sağlanabilir.

- Danışmanlık hizmeti sunan kurum ya da kuruluşlar, işletmelerin onlara ulaşmasını beklemeden, işletmelerle iletişime geçebilir.

- Kastamonu halkına ve/veya turizm işletmesi çalş̧anlarına turizm eğitimi verilerek nitelikli personel olmaları için çaba gösterilebilir.

Yazar Katkıları: Bu çalışmanın alan araştırması bölümlerinde birinci yazar olan Ali ŞENGÜL, verilerin analizi bölümlerinde ise ikinci yazar Hüseyin PAMUKÇU ve üçüncü yazar Semih ARICI katkı sağlamıştır.

Çıkar Beyanı: Bu çalışmada çıkar çatışması bulunmamaktadır. Tüm yazarlar ortak işbirliği içerisinde bu çalışmayı hazırlamıştır.

\section{Kaynakça}

Akbaba, A. (2012). Destinasyon geliştirme ve küçük ölçekli turizm işletmeleri: Akçakoca üzerine bir inceleme. Abant İzzet Baysal Üniversitesi Sosyal Bilimler Enstitüsü Dergisi, 12(1), $1-16$.

Akmel, J. (1992). Turizm hizmeti veren işletmeler ve belediyeler. Anatolia: Turizm Araştırmaları Dergisi, 3(4), 14-15.

Aktürk, T. (2019). Hizmet sektöründe işletme sermayesi ihtiyacı: turizm sektöründe bir araştırma (Yüksek Lisans Tezi). Gazi Üniversitesi Sosyal Bilimler Enstitüsü, Ankara.

Aytar, D. (1999). Danışmanlık: nedir? ne değildir? İstanbul: Rota Yayıncılık.

Barutçugil, S. İ. (1989). Turizm işletmeciliği. İstanbul: Beta Basım Dağıtım.

BDO(2020, Aralık). Danışmanlık hizmetleri. Erişim adresi: https://www.bdo.com.tr/.

Bildirgen, M. B. (2010). İşletmelerin danışman kullanma eğilimlerinin belirlenmesi ve danışman seçiminde izledikleri yöntemler (Yüksek Lisans Tezi). Hacettepe Üniversitesi Sosyal Bilimler Enstitüsü, Ankara. 
Çetinkaya, A. Ş. (2007). Bilişim teknolojilerinin konaklama işletmeleri performansına etkileri: beş yıldızlı otellere yönelik bir araştırma (Yüksek Lisans Tezi). Selçuk Üniversitesi Sosyal Bilimler Enstitüsü, Konya.

Doğan, S., Şanlıer, N., \& Tuncer, M. (2010). Yiyecek-içecek işletmelerinin satış çabalarında etik: Kastamonu ili örneği. Kastamonu Eğitim Dergisi, 18(1), 241-256.

Emir, O., Pelit, E., Günay, F. (2010). Üniversite mezunu çalışanların bakış açısıyla otel işletmelerinin sorunları: Antalya'daki 5 yıldızlı otel işletmelerinde bir uygulama. İş Güç, Endüstri İlişkileri ve İnsan Kaynakları Dergisi, 12(4), 7-31.

Erdost, H. E. (2002). Danışmanlık hizmeti ve ülkemizde yönetim danışmanlığı firmaları (Doktora Tezi). Ankara Üniversitesi Sosyal Bilimler Enstitüsü, Ankara.

Güven, M. (1999). Turizm işletmeleri ve muhasebe uygulamaları. Ankara: TÜRMOB Yayınları Sirküler Rapor Serisi No: 25.

HMT Otel Yatırım ve İşletme Danışmanlığı(2020, Aralık). Danışmanlık Hizmetleri. Erişim adresi: https://www.hmthotel.com/.

Kayabaşı, S. (2009). Yönetim danışmanlığı ve işletmelerin yönetim danışmanlığına bakış açıları: Marmara bölgesinde faaliyet gösteren işletmeler üzerinde bir araştırma (Yüksek Lisans Tezi). Sakarya Üniversitesi Sosyal Bilimler Enstitüsü, Sakarya.

Kaynak, İ. (2020). Yönetim danışmanlığı ve danışmanlığın değeri (Doktora Tezi). İstanbul Gelişim Üniversitesi Sosyal Bilimler Enstitüsü, İstanbul.

Kılıç, B. (2020). Konaklama işletmelerinde yönetim danışmanlarına danışma gereği ve öneriler. Uluslararası Global Turizm Araştırmaları Dergisi, 4(1), 33-45.

Kirby, D. A., \& Dylan, J. E. (1997). Small technology-based professional consultancy services in the United Kingdom. Service Industries Journal, 17(1), 155-172.

Kotler, P., Bowen, J. T., Makens, J. C., \& Baloglu, S. (2017). Marketing for hospitality and tourism Seventh Edition. Boston: Pearson Limited Education.

Kozak, N. (2010). Turizm pazarlaması. Ankara: Detay Yayıncılık.

Kozak, N., Kozak, M. A., \& Kozak, M. (2014). Genel turizm bilgisi ilkeler-kavramlar. Ankara: Detay Yayıncilik.

Mitchell, V. W. (1994). Problems and risks in the purchasing of consultancy services. Service Industries Journal, 14(3), 315-339.

Muhammad, G., Ibrahim, J., Bhatti, Z., \& Waqas, A. (2014). Business intelligence as a knowledge management tool in providing financial consultancy services. American Journal of Information Systems, 2(2), 26-32.

NY\&Co. Global Hospitality Consultancy(2020, Aralık). Danışmanlık Hizmetleri. Erişim adresi: https://www.nytmco.com/.

Nural, C. (1991). Sanayi kesimine eğitim ve eğitim veren kuruluşların yapısal analizi (Yüksek Lisans Tezi). İstanbul Teknik Üniversitesi Sosyal Bilimler Enstitüsü, İstanbul.

Özcan, S., (2018). Termal turizm işletmeleri ile diğer konaklama işletmelerinin maliyet yönetimi açısından karşılaştırılması: Çanakkale örneği (Yüksek Lisans Tezi). Çanakkale Onsekiz Mart Üniversitesi Sosyal Bilimler Enstitüsü, Çanakkale

Şen, L. M. (2013). Konaklama işletmelerinde faaliyet tabanlı bütçeleme ve beş yıldızlı otel işletmesi uygulaması (Doktora Tezi). Sakarya Üniversitesi Sosyal Bilimler Enstitüsü, Sakarya. 
Şenel, S. A. (2007). Turizm sektöründe yatırım kararları. Karamanoğlu Mehmetbey Üniversitesi Sosyal ve Ekonomik Araştırmalar Dergisi, 2007(1), 1-12.

TEAM Tourism Consulting(2020, Aralık). Danışmanlık Hizmetleri. Erişim adresi: https://www.team-tourism.com/.

Tunalı, N. (1999). İşletmelerde yönetim danışmanlığı hizmetlerinin kullanımı ve Türkiye'deki uygulamasına yönelik araştırma (Yüksek Lisans Tezi). Anadolu Üniversitesi Sosyal Bilimler Enstitüsü, Eskişehir..

Tunçsiper, B., İlban, M. O. (2006). Turizm işletme belgeli otel işletmelerinin pazarlama sorunları: Balıkesir ilinde bir alan araştırması. Sosyal Bilimler Dergisi, 6(1), 225-244.

Turizoom Otel Yönetim Danışmanlı̆̆ı(2020, Aralık). Danışmanlık Hizmetleri. Erişim adresi: https://www.turizoom.com/.

Yıldırım, A., \& Şimşek, H. (2005). Sosyal bilimlerde nitel araştırma teknikleri. Ankara: Seçkin Yayıncilik.

Yisa, S., \& Edwards, D. J. (2002). Evaluation of business strategies in the UK construction engineering consultancy. Measuring Business Excellence, 6(1), 23-31.

Wilson, A., (1972). The marketing of professional services. New York: McGraw Hill Companies. 